[Appeared as: Jiménez, Jesús \& Maria-Rosa Lloret. 2013. Vocalic adjustments under Positional Markedness in Catalan and other Romance languages. In Camacho-Taboada, V.; Jiménez-Fernández, Á. L.; Martín-González, J.; Reyes-Tejedor, M. (eds.), Information Structure and Agreement. (Linguistik Aktuell/Linguistics Today, 197). 319-336. Amsterdam / Philadelphia: John Benjamins. Available at https://benjamins.com/\#catalog/books/la.197/main. The publisher should be contacted for permission to re-use or reprint the material in any form.]

\title{
Vocalic adjustments under Positional Markedness in Catalan and other Romance languages ${ }^{*}$
}

\author{
Jesús Jiménez (Universitat de València), jesus.jimenez@uv.es
}

\section{Maria-Rosa Lloret (Universitat de Barcelona), mrosa.lloret@ub.edu}

\begin{abstract}
While in a wide range of phonological theories preservation under prominence is a well noticed effect, there are few explanations for the accumulation of prominent properties in a particular position. Both tendencies, however, as well as their interaction, are particularly suited to formal expression within Optimality Theory. The aim of this paper is to show that the word-initial position is a site of vowel preservation (Positional Faithfulness) and a point of attraction of salient features (Positional Markedness). The focus is on the less familiar effect of get-together prominent elements in order to shed new light on several vocalic adjustments that have been unsatisfactorily explained in the traditional literature of Romance languages.
\end{abstract}

Keywords: Vowel change, epenthesis, prominence, Positional Faithfulness, Positional Markedness, Optimality Theory, Catalan, Romance languages.

\footnotetext{
* An earlier version of this paper was presented at the XXVI Congrés Internacional de Lingüística i Filologia Romàniques, València 2010. The audience of this conference as well as that of the $21^{\text {st }}$ Colloquium on Generative Grammar, Sevilla 2011, provided valuable discussion on some aspects of the work. The comments of two anonymous reviewers were also very helpful. The research has been supported by the Spanish Ministerio de Economía y Competitividad and the FEDER (project number FFI201022181-C03-02), and by the Generalitat de Catalunya (research group 2009SGR521).
} 


\section{Introduction}

Since the Prague School's work, the concept of 'prominence' has been used to explain some asymmetries attested in the world languages regarding the different behavior of segments which are alike except for the structural position in which they appear. The most common use of prominence in phonological theories relates to observations about the grammatical pressure to protect elements that appear in strong positions (syllable peaks, onsets, stressed syllables, heads of prosodic words, stems, etc.); in contrast, elements attached to weaker positions (syllable margins, codas, unstressed syllables, non-heads of prosodic words, affixes, etc.) are more vulnerable and hence are more prone to change. For example, many languages display neutralization processes in weak positions (e.g. assimilation in codas, vowel reduction in unstressed syllables, devoicing in word-final position), but not in strong positions. There is yet a less familiar effect of prominence related to the intrinsic properties of elements: more prominent elements tend to link to structurally strong positions, whereas weaker elements tend to attach to less salient positions. For instance, in many languages stress (a salient feature) is preferably located on heavy, closed syllables (a prominent position with respect to light, open syllables).

While in a wide range of phonological theories preservation under prominence is a well noticed effect, there are fewer explanations for the accumulation of salient properties in a particular site. Both tendencies, however, as well as their interaction, are particularly suited to formal expression within Optimality Theory (OT; Prince \& Smolensky 1993/2004). In OT, to deal with preservation under prominence, faithfulness constraints protecting elements in strong positions must outrank markedness constraints (Positional Faithfulness; cf. Alderete 1995, Beckman 1998); while to explain the 
attraction of prominent elements to strong positions, markedness constraints favoring more salient elements in those positions must become active, sometimes outranking certain faithfulness constraints (Positional Markedness; cf. Prince \& Smolensky 1993/2004).

The aim of this paper is to show that the word-initial position is a site of vowel preservation as well as a point of attraction of salient features; examples are from Catalan and other Romance languages, and the focus is on the less common effect of get-together prominent characteristics. We first briefly discuss the relation between the prominence of the word-initial position and segmental prominence (§ 2). Second, we examine cases where some features that are retained word-initially are overridden in other sites (§ 3). Third, we show that prominent features tend to couple with prominent positions and, in particular, with the word-initial position (§ 4). Finally, we develop an analysis for the asymmetric behavior of pronominal proclitics and enclitics in Pedreguer (Valencian Catalan) from the perspective of Positional Markedness (§ 5).

\section{Prominence: Word-initial position and sonority}

The singularity of the word-initial position has long been noticed in the past. As an example from the diachronic studies on Spanish, Menéndez Pidal (1985: § 16) observes that ‘...[l]a posición inicial es la más firme, la que da más resistencia a las vocales, la que más las asemeja a la acentuada...' ['...the initial position is the most stable, the position which makes vowels more resistant to changes, the most similar to the stressed position...']. More recent studies have empirically demonstrated the relevance of this position. Different psycholinguistic experiments on word recognition (more efficient at the beginning of the word) and effects derived from word distortion (which are considered worse if the deviant part is at the beginning of the word) have determined 
that the left part of the word is more relevant than the end of the word. This has been related to the importance of temporal structure in languages or to the lexical access to words, from left to right (cf. Nooteboom 1981, Hawkins \& Cutler 1988, Barnes 2002, Chitoran et al. 2002). From a phonetic point of view, Barnes (2002) has further proved that several effects attributed to the initial syllable are, in fact, strictly induced by the vowel appearing at the absolute left edge of the word, since this segment, among other things, is clearly longer than other vowels. Other scholars have argued that word-initial consonants may have a special status as well, which has to do with prominent effects stemming from the position in which they are located (see, among others, Chitoran et al. 2002).

All in all, we end up having the hierarchy for prominence presented in (1a), which, when limited to the specific position under discussion in the present paper, establishes that the initial position of the word is stronger than non-initial sites (1b).

(1) Positional prominence hierarchy:

a. General scheme: Peak (strong position) > Margin (weak position)

b. Particular case: Initial (strong position) > Non-initial (weak position)

There is also a broad consensus in the literature that there is a hierarchy for segmental prominence coupled with sonority, according to which the more sonorous a segment is the more prominent it is. ${ }^{1}$ In spite of some disagreements over the details of the sonority scale, there is a widespread agreement with the hierarchy of segmental sonority sketchily presented in (2).

\footnotetext{
${ }^{1}$ It is worth noting that some authors question the very concept of sonority (e.g. Ohala \& Kawasaki-Fukumori 1997), though not necessarily deny the existence of syllables. Alternatives to the sonority hierarchy for explaining segmental sequential constraints appear, for instance, in Blevins (2003).
} 
(2) Segmental prominence hierarchy:

$\mathrm{a}>\varepsilon, \mathrm{\rho}>\mathrm{e}, \mathrm{o}>\mathrm{i}, \mathrm{u}>\mathrm{\rho}>\ldots>\mathrm{p}, \mathrm{t}, \mathrm{k}$

The segmental prominence hierarchy of (2) interacts with the positional prominence hierarchy of (1). The result of this crossing is a set of markedness sonorityreferring related constraints which mention a structural place (a peak - a syllable nucleus, for instance - or a margin - a syllable onset or a coda, for example), inherently ranked with respect to one another following the order of the hierarchy in (2). Thus, vowels, which are the most sonorous elements, are the segments that better suit strong positions and hence syllable nuclei or peaks (P) (3a); inversely, the most sonorous segments are the worst elements in weak positions and hence in syllable margins (M), i.e. onsets and codas (3b). ${ }^{2}$

(3) a. *P/p,t,k $>>\ldots>>\mathrm{P} / \mathrm{a}>>* \mathrm{P} / \mathrm{i}, \mathrm{u}>>* \mathrm{P} / \mathrm{e}, \mathrm{o}>>* \mathrm{P} / \mathrm{\varepsilon}, \mathrm{o}>>* \mathrm{P} / \mathrm{a}$

b. ${ }^{*} \mathrm{M} / \mathrm{a}>>* \mathrm{M} / \varepsilon, \mathrm{o}>>* \mathrm{M} / \mathrm{e}, \mathrm{o}>>* \mathrm{M} / \mathrm{i}, \mathrm{u}>>* \mathrm{M} / \mathrm{\rho}>>\ldots>>* \mathrm{M} / \mathrm{p}, \mathrm{t}, \mathrm{k}$

As a particular instance of these patterns, the hierarchy of segmental prominence associates with the prominence of the initial position of the word in two different ways: under Positional Faithfulness, constraining vowel reduction (§ 3), and under Positional Markedness, piling up prominent features in that position (§ 4).

\section{Word-initial position and Positional Faithfulness}

As mentioned, the claim that the initial position of words is a privileged site to preserve elements that are otherwise overridden appears in classic works recurrently. For instance, the crucial role of the left edge is invoked to explain why, in the evolution

\footnotetext{
${ }^{2}$ At this point, it is important to observe that the peak constraints in (3a) focus on the prominent member of the hierarchy (1a), namely, the syllable nucleus (a vowel in our examples), though we will next present different crossings regulating more specific relations between vowel-sonority and the relatively more or less prominent peak positions (e.g. stressed vs. unstressed, word-initial vs. non-word-initial).
} 
from Latin to Romance languages, unstressed vowels that tend to be deleted in other positions regularly resist in word-initial position (4).

(4) APRILE 'April’ > abril (Cat., Gal., Port., Sp.), avril (Fr.), aprile (It.), aprilie (Rum.)

HIBERNU ‘winter’ > hivern (Cat.), hiver (Fr.), inverno (Gal., It., Port.), iarna (Rum.), invierno (Sp.) ${ }^{3}$

The examples in (5) present additional cases of preservation of underlying vocalic features in unstressed word-initial position. In Catalan and Spanish, hiatuses are maintained to block the formation of rising diphthongs in initial syllables - i.e. to prevent changes in high vowels in unstressed initial syllables -, while in non-initial positions high unstressed vowels can become a glide (5a) (Cabré \& Prieto 2006). Similarly, in some verbal forms of the Valencian variety of Canals, unstressed open mid-vowels are preserved in absolute word-initial position, whereas in other positions they reduce to close mid-vowels (5b) (Sancho Cremades 1995), and in Galician, open mid-vowels in unstressed syllables that occur not only word-initially but also pretonically can be maintained, instead of reducing to close mid-vowels (5c) (Freixeiro 2006).

(5) a. b[i.ó]leg 'biologist’ vs. rad[jó]leg 'radiologist' (Cat.) b[i.ó]logo ‘biologist’ vs. rad[jó]logo 'radiologist’ (Sp.)

b. [o]brim 'we open', [0]mplim 'we fill' vs. $\mathrm{p}[\mathrm{o}] \mathrm{rtem},{ }^{*} \mathrm{p}[$ ○]rtem 'we bring' (Valencian variety of Canals)

c. [o]sudo 'bony', v[o]tar 'to vote'

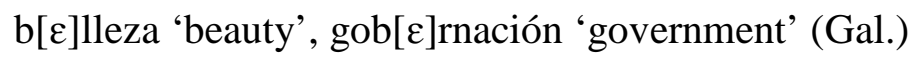

\footnotetext{
${ }^{3}$ Cat. $=$ Catalan; Fr. $=$ French; Gal. $=$ Galician; It. $=$ Italian; Port. $=$ Portuguese; Rum. $=$ Rumanian; Sp. = Spanish.
} 
We illustrate the OT analysis under Positional Faithfulness with the exceptional verbal forms of Canals (5b). As claimed before, as a general rule the more sonorous a vocalic nucleus is, the better it is (6a); but in unstressed position $\left(\mathrm{P}_{\mathrm{UNSTR}}\right)$, which is a weak position with respect to the stressed position, the less sonorous a vowel is, the better it is, with the inverse sonority relation presented in (6b) (cf. Crosswhite 1999, 2004 and, for Catalan, Wheeler 2005: § 2.3). Note that in (6a) the constraints of the hierarchy are ranked in order of increasing sonority, capturing the fact that high sonority-prominence (i.e. open mid-vowels in our example) is preferred in the prominent peak position; in (6b) instead the constraints of the hierarchy are ranked in order of decreasing sonority, capturing the fact that low sonority-prominence (i.e. close mid-vowels in our case) is preferred in unstressed (and hence prosodically weaker) positions. The markedness-related constraints in (6) interact with the faithfulness constraint in (7), which preserves the value for the feature [ \pm open] in vowels appearing in the - prominent - absolute initial position (a Positional Faithfulness effect); the general faithfulness constraint in (8), on the other hand, protects all instances of the feature [ \pm open], regardless of its appearance in prominent or non-prominent sites.

(6) $\quad$ a. $* \mathrm{P} / \mathrm{e}, \mathrm{o}>>* \mathrm{P} / \varepsilon, \mathrm{o}$

b. $* \mathrm{P}_{\mathrm{UNSTR}} / \varepsilon, \mathrm{o}>>* \mathrm{P}_{\mathrm{UNSTR}} / \mathrm{e}, \mathrm{o}$

(7) IDENT[ $[ \pm$ open $]-V_{\text {Initial }}\left(\operatorname{ID}[ \pm\right.$ open $\left.]-V_{\text {In }}\right)$ : The value for $[ \pm$ open] in the input (I) is the same as that of its correspondent in the output $(\mathrm{O})$, if the vowel appears at the beginning of the word.

(8) IDENT[ $[ \pm$ open]-V (ID[ \pm open]-V): The value for $[ \pm$ open] in the I is the same as that of its correspondent in the $\mathrm{O}$. 
The combination of these constraints in the hierarchy in (9) leads to the right results. The tableaux in (10) and (11) exemplify the ranking at work. In (10), the ranking of the faithfulness constraint $\operatorname{ID}\left[ \pm\right.$ open] $-\mathrm{V}_{\text {In }}$ at the top of the hierarchy discards the candidate that modifies the input vowel located word-initially, (10b). In (11), the same faithfulness constraint does not block featural changes in the first vowel with respect to [ \pm open] because it does not appear in absolute word-initial position; hence, the optimal candidate correctly exhibits a reduced (less sonorous) unstressed vowel, (11b).

(9) $\mathrm{ID}[ \pm$ open $]-\mathrm{V}_{\mathrm{In}}>>* \mathrm{P}_{\mathrm{UNSTR}} / \varepsilon, \boldsymbol{\rho}>>* \mathrm{P}_{\mathrm{UNSTR}} / \mathrm{e}, \mathrm{o}, \mathrm{ID}[ \pm$ open $]-\mathrm{V}$

(10) Input: /o'brim/ 'we open'

\begin{tabular}{|c|c|c|c|c|}
\hline Candidates & ID $[ \pm$ open $]-V_{\text {In }}$ & $* \mathrm{P}_{\mathrm{UNSTR}} / \varepsilon, \mathrm{\rho}$ & $* \mathrm{P}_{\mathrm{UnSTR}} / \mathrm{e}, \mathrm{O}$ & ID[ $[ \pm$ open $]-V$ \\
\hline$\varpi$ a. o'ßrim & & * & & \\
\hline b. o'ßrim & $* !$ & & * & * \\
\hline
\end{tabular}

(11) Input: /por'tem/ 'we bring'

\begin{tabular}{|c|c|c|c|c|}
\hline Candidates & ID[ \pm open $]-\mathrm{V}_{\text {In }}$ & $* \mathrm{P}_{\mathrm{UNSTR}} / \varepsilon, \mathrm{o}$ & $* \mathrm{P}_{\mathrm{UNSTR}} / \mathrm{e}, \mathrm{o}$ & $\mathrm{ID}[ \pm \mathrm{open}]-\mathrm{V}$ \\
\hline a. por'tem & & $* !$ & & \\
\hline$\sigma$ b. por'tem & & & $*$ & $*$ \\
\hline
\end{tabular}

\section{Prominent positions and Positional Markedness}

The initial position of words, as other salient positions, tends to attract prominent features. Because of that, input vowels are sometimes replaced with more sonorous vowels in that site. Traditionally, some of the changes related to the initial position have been attributed to underlying tendencies that are not properly understood. For example, 
Menéndez Pidal (1985: $§ ~ 203$ ) states: 'Lo mismo que la $e$ inicial, $O$ se puede cambiar en $a$, ayudando oscuras asimilaciones o disimilaciones a cierta preferencia otorgada a la $a$ inicial como vocal más clara...' ['As the initial $e, O$ can change to $a$, with the help of obscure assimilations and dissimilations as well as a certain preference for the vowel $a$ in initial position as the clearest vowel...']; cf. the Spanish examples NOvACULA > navaja 'pocketknife', *COLOSTRU > calostro 'colostrum'.

In OT, the accumulation of salient properties belonging to different grammatical components is seen as a way to improve the outcome: the isomorphism between levels increases the structural iconicity of the whole, since properties which are prominent are highlighted in different levels and properties which are less relevant are faded. In other words, stronger positions are reinforced whereas weaker positions weaken even more, a tendency which is captured in Natural Phonology under the Rich-get-richer Principle (cf. Donegan 1978: 143). From this perspective, alleged 'obscure' changes such as the aforementioned vocalic shifts of Spanish become comprehensible.

Further examples that support this interpretation involve the preference for open vowels in the mid series ([ع] instead of [e], [o] instead of [o]) in certain prominent positions. We can interpret in such way, for instance, the opening of [o] as [0] in stressed initial syllables in Catalan (12), a phenomenon which is left unmotivated in classic studies (cf. Moll 2006: 62, Coromines 1971: 189-195, Gulsoy 1993: 90-94).

(12) fl[ó]r 'flower' $\mathrm{n}[$ ó]m 'name' $\mathrm{h}$ [ó]ra 'hour'

The same reason has been adduced to explain the tendency to realize as open the stressed mid-vowels that appear in loanwords and learned words in Romance languages, 
irrespective of the quality of the original vowel (13). This trend has been reported to be active, e.g., in Italian (13a), Catalan (13b), and Galician (13c). ${ }^{4}$

(13) a. $\operatorname{dev[ó]to~'devout',~r[ع́]gola~'rule’~(It.;~cf.~Franceschi~1968,~Kenstowicz~}$ 2010)

b. est[ó]p ‘stop’, [ć]tica ‘ethics’ (Cat.; cf. Fabra 1906, Badia 1968, 1970, PiMallarach 1997, Cabré 2002, 2009, Wheeler 2005, Bonet et al. 2007, Mascaró 2008, 2011, Jiménez \& Lloret 2010)

c. st[ó]p 'stop', [ć]tica 'ethics’, b[ó]la 'sphere’ (vs. b[ó]la 'bread ball’) (Gal.; cf. Freixeiro 2006, DPLG) ${ }^{5}$

As we will next exemplify with the analysis of loanword adaptation in Catalan, in OT these are cases of the emergence of the unmarked (a TETU effect). The relevant constraints at play are the peak-related constraints of the ranking presented in (6a), which show the same order of increasing sonority when specifically referred to prominent stressed (and hence prosodically strong) positions (14), and the faithfulness constraint defined in (15) against changes in the open value of stressed vowels.

$$
* \mathrm{P}_{\mathrm{STR}} / \mathrm{e}, \mathrm{o}>>* \mathrm{P}_{\mathrm{STR}} / \varepsilon, \mathrm{o}
$$

(15) IDENT[ $[ \pm$ open $]-V_{\text {Stressed }}\left(\operatorname{ID}[ \pm\right.$ open $\left.]-V_{\text {Str }}\right)$ : The value for $[ \pm$ open $]$ in the $\mathrm{I}$ is the same as that of its correspondent in the $\mathrm{O}$, if the vowel is stressed.

The ranking of the faithfulness constraint ID[ \pm open]- $\mathrm{V}_{\mathrm{Str}}$ over the markednessrelated peak constraints, (16), accounts for the facts straightforwardly. The tableau in

\footnotetext{
${ }^{4}$ In Italian, this tendency was defined by Migliorini (1945: 46, 1990: 22) with the formula 'vocale incerta, vocale aperta' ['uncertain vowel, open vowel']; see Franceschi (1968) and Kenstowicz (2010) as well.

${ }^{5}$ In the online DRAG, which contains a sound file for each entry, stop and ética (and similar words) are given with both open and close mid stressed vowels, while bóla and bola are minimal pairs with open and close mid stressed vowels, respectively.
} 
(17) illustrates that patrimonial words, which have an underlying specification for [ \pm open] in the input vowels, surface as open or closed due to faithfulness constraints. Instead, the tableau in (18) shows that loanwords, whose vowels do not crucially have any specified value for openness in the input and hence cannot incur any faithfulness violation, surface with mid-open vowels, because the markedness constraints can freely choose the more sonorous (open) segment to better suit the stressed position. ${ }^{6}$

$$
\mathrm{ID}[ \pm \text { open }]-\mathrm{V}_{\mathrm{Str}}>>* \mathrm{P}_{\mathrm{STR}} / \mathrm{e}, \mathrm{o}>>* \mathrm{P}_{\mathrm{STR}} / \varepsilon, \mathrm{o}
$$

(17) Input: /'seg/ 'blind'

\begin{tabular}{|c|c|c|c|}
\hline Candidates & ID[ \pm open]- $\mathrm{V}_{\mathrm{Str}}$ & $* \mathrm{P}_{\mathrm{STR}} / \mathrm{e}, \mathrm{o}$ & $* \mathrm{P}_{\mathrm{STR}} / \varepsilon, \mathrm{o}$ \\
\hline a. 'sek & & $*$ & \\
\hline b. 'sck & $* !$ & & $*$ \\
\hline
\end{tabular}

(18) Input: /'tfEk/ 'check'; E = mid-vowel without [ \pm open] specification

\begin{tabular}{|c|c|c|c|}
\hline Candidates & $\mathrm{ID}[ \pm$ open $]-\mathrm{V}_{\mathrm{Str}}$ & $* \mathrm{P}_{\mathrm{STR}} / \mathrm{e}, \mathrm{O}$ & $* \mathrm{P}_{\mathrm{STR}} / \varepsilon, \supset$ \\
\hline a. 't $\mathrm{t}$ ek & & $* !$ & \\
\hline b. 't $\int \varepsilon k$ & & & * \\
\hline
\end{tabular}

Contrary to the effects observed in stressed position, vowels in unstressed syllables tend to reduce to less sonorous vowels, since the output vowels are less prominent (less sonorous) than the underlying vowels which they replace and hence better suit this weak position, as shown in (19) and (20) for Catalan. ${ }^{7}$

\footnotetext{
${ }^{6}$ Bonet et al. (2007) and Cabré (2010) develop an OT analysis of loans and learned words in Catalan along the same Positional Markedness view.

${ }^{7}$ A thorough presentation on the OT analysis of vowel reduction appears in Crosswhite (1999, 2004) and for Catalan, in Wheeler (2005: § 2.3). The basic pattern of vowel reduction in Valencian Catalan has been exemplified in (11).
} 
(19) General scheme of vowel reduction in Central Catalan:

$$
\begin{aligned}
& {[ə]</ / \mathrm{a} /, / / \mathrm{l} /, / / \mathrm{e} /} \\
& {[\mathrm{u}]</ \mathrm{\prime} /, / / \mathrm{O} /}
\end{aligned}
$$

(20) General scheme of vowel reduction in Valencian Catalan:

$$
\begin{aligned}
& {[\mathrm{e}]</ \mathrm{l} \varepsilon /} \\
& {[\mathrm{o}]</ \mathrm{/} /}
\end{aligned}
$$

In the two sites, i.e. in the stressed (prominent) position and in the unstressed (non-prominent) position, there is a tendency to make converge the syllable prominence or lack of prominence, on the one hand, and the segmental prominence or lack of prominence, on the other. Yet, important differences in prominence among unstressed syllables are further documented, which indicate that more open segments usually appear in the most prominent position among the unstressed syllables, i.e. the initial position. For example, in Valencian Catalan, [a] tends to appear instead of expected [e] at the very beginning of word-initial closed syllables both if the vowel is epenthetic, which in other positions is [e], (21a), and if it derives from an underlying /e/, (21b). The shift to [a] affects, in a less systematic way, some vowels that appear in the first syllable but are not in absolute initial position, especially if they occur in closed syllables (21c) (cf. Lloret \& Jiménez 2008). ${ }^{8}$

\footnotetext{
${ }^{8}$ Some sporadic changes from $\overline{\mathrm{E}} / \breve{\mathrm{E}} / \breve{\mathrm{I}}, \overline{\mathrm{O}} / \breve{\mathrm{O}} / \breve{\mathrm{U}}$ (in Classical Latin) to $a$ (in Vulgar Latin or Early Romance) that have been reported in classic works seem to follow the same pattern: BILANCEA 'scales' > balança (Cat.), balanza (Sp.); SILVATICU 'wild' > salvatge (Cat.), salvaje (Sp.); NOVACULA 'pocketknife' > navalla (Cat.), navaja (Sp.); *COLOSTRU ‘colostrum' > calostre (Cat.), calostro (Sp.).
} 
(21) a. SPINA > espina > aspina 'thorn, spine', sCALA > escala > ascala 'stairs'

b. IMBUTU $>$ embut $>$ ambut 'funnel', INTENDERE $>$ entendre $>$ antendre 'understand'

c. bescoll > bascoll 'neck' vs. t(r)esor > *t(r)asor 'treasure'

Valencian varieties, though, differ as far as the domain to which the distinction between Initial and Non-initial applies. All varieties consider the initial position of lexical words especially salient, as shown in [a]spina, (22), where the most sonorous vowel, [a], is selected as epenthesis. (From now on, epenthetic vowels are underlined for clarity.)

(22) [a]spina 'thorn, spine'

Compared with the word domain, elements added in a broader domain such as the clitic group (where clitics form a prosodic unit with the host to which they attach) may be considered less salient. ${ }^{9}$ Taking that into account, some Valencian dialects, such as the variety spoken in Canals, prefer [e] as epenthetic vowel in domains beyond the prosodic word, as the examples in (23) show for the $1^{\text {st }}$ person singular clitic $/ \mathrm{m} /$, as a single clitic and in combination with the $3^{\text {rd }}$ person accusative clitics /1/ (masculine) and /la/ (feminine) (cf. Sancho Cremades 1995). ${ }^{10}$

\footnotetext{
${ }^{9}$ Among other typical characteristics of weak elements, pronominal clitics do not carry primary stress, are functional elements, and only add grammatical information.

10 The observations about the clitics in different Valencian varieties that we are highlighting mainly stand for the $1^{\text {st }}$ person singular clitic $/ \mathrm{m} /\left(\mathrm{cf}\right.$. (23)-(25)), the $2^{\text {nd }}$ person singular clitic $/ \mathrm{t} /$, and the $3^{\text {rd }}$ person reflexive clitic $/ \mathrm{s} /$. Other clitics might show more variation for independent reasons.
} 
(23) [e]m porta

$\mathrm{m}[\mathrm{e}]$ 'l porta

portar-m[e]

portar-m[e]-la 's/he brings me'

's/he brings him to me'

'to bring me'

'to bring her to me'

However, there may be a contrast between [a]-insertion at the very beginning of the clitic group (24a) and [e]-insertion in other sites (24b), if the relevance of the initial position extends to the clitic group domain, as it is the case in the Valencian variety of Benissa (Beltran 1997).
(24) a. [a] $] \mathrm{m}$ porta
's/he brings me'
b. m[e]'l porta
's/he brings him to me'
portar-m[e] 'to bring me'
portar-m[e]-la 'to bring her to me'

A noteworthy variant of the pattern in (24), which will be analyzed in more detail in $\S 5$, is found in the town of Pedreguer, where a distinction is made solely on the basis of proclisis, where [a] is normally selected as the epenthetic vowel (25a), and enclisis, where [e] is selected as the epenthetic vowel (25b) (Garcia \& Beltran 1994, Beltran 2005).

(25) a. Proclisis: [a]m porta, m[a]'l porta

b. Enclisis: portar-m[e], portar-m[e]-la 


\section{Effects of Positional Markedness in Pedreguer pronominal clitic system}

The pronominal clitics of Catalan exhibit a considerable contextual variation in their phonetic realization within individual dialects. The formal variation depends on different factors, some of which involve the quality and site of the epenthetic vowel that is sometimes required for syllabification. For the purpose of this paper, this section only focuses on the quality of the epenthetic vowel, ignoring discussion on the nature of vowels others than epenthetic [e] [a] and the principles that guide clitic syllabification (see Bonet \& Lloret 2005, Wheeler 2005: § 11). Particularly to be noted is the fact that in Pedreguer asyllabic clitics (i.e. clitics with a /C(C)/ shape) add [a] in proclisis (26) but [e] in enclisis (27) (Garcia \& Beltran 1994, Beltran 2005). ${ }^{11}$ For the sake of comparison, (26) and (27) include information on syllabic clitics as well (i.e. clitics with a /CV(C)/ shape which do not need epenthesis for their syllabification). Note also that $3^{\text {rd }}$ person accusative masculine clitics and the $3^{\text {rd }}$ person plural dative clitic show underlying allomorphy (/l/ /lo/, /lz/ /loz/), distributed according to their position and syllabification needs: basically, the syllabic forms (i.e. /lo/ and /loz/) only appear in enclisis for syllabic reasons. $^{12}$

\footnotetext{
${ }^{11}$ The appearance of [e] is invariant in enclisis, both in single clitics (portar-m[e]) and in clitic clusters (portar-m[e]-la). In proclitic clusters, although the choice of epenthetic [a] is clearly dominant, it sometimes occurs in variation with [e] ([a]m porta, but $m$ [a]'l $\sim m[\mathrm{e}]$ 'l porta). Further investigation is required to tackle the variation issue.

${ }^{12} 1=1^{\text {st }}$ person, $2=2^{\text {nd }}$ person, $3=3^{\text {rd }}$ person; SG $=$ singular, $\mathrm{PL}=$ plural; MASC $=$ masculine, $\mathrm{FEM}=$ feminine; $\mathrm{REFL}=$ reflexive, $\mathrm{ACC}=$ accusative, $\mathrm{DAT}=$ dative .
} 
(26) Clitics in proclisis (before a host starting in a consonant)

\begin{tabular}{|c|c|c|c|c|c|}
\hline & \multirow{3}{*}{$\begin{array}{l}\text { SINGLE } \\
\text { CLITICS }\end{array}$} & \multicolumn{4}{|c|}{ CLITIC CLUSTERS } \\
\hline & & \multicolumn{4}{|c|}{ (left column forms + ACC clitics) } \\
\hline & & $/ 1 /$ & $/ \mathrm{la} /$ & $/ \mathrm{lz} /$ & /lez/ \\
\hline$/ \mathrm{m} /{ }^{\prime} 1 \mathrm{sG}$ ' & [am] & [mall] & [mala] & [mals] & [males] \\
\hline$/ \mathrm{t} /$ '2sG' & [at] & [tal $]$ & [tala] & {$[\mathrm{ta}(1) \mathrm{s}]$} & [tales] \\
\hline /S/ '3REFL' & [as] & [sall] & [sala] & [sals] & [sales] \\
\hline$/ \mathrm{moz} /$ '1PL' & [mos] & $\begin{array}{c}\text { [mol] } \\
\text { [mozall] }\end{array}$ & [mola] & $\begin{array}{c}\text { [mols] } \\
\text { [mozals] }\end{array}$ & [moles] \\
\hline /voz/'2PL' & [vos] & $\begin{array}{c}\text { [vol] } \\
\text { [vozall] }\end{array}$ & [vola] & $\begin{array}{c}\text { [vols] } \\
\text { [vozals] }\end{array}$ & [voles] \\
\hline /li/ '3DAT.SG' & [li] & [lil] & [lila] & [li(1)s] & [liles] \\
\hline /lz/ 'ЗDAT.PL' & [als] & [alzall] & [alzala] & [alzâa(l)s] & [alzales] \\
\hline /1/ ‘3ACC.MASC.SG’ & [al] & & & & \\
\hline /la/ '3ACC.FEM.SG' & [la] & & & & \\
\hline /lz/ 'ЗACC.MASC.PL' & {$[\underline{a}(1) \mathrm{s}]$} & & & & \\
\hline /lez/ 'ЗАСC.FEM.PL' & [les] & & & & \\
\hline
\end{tabular}


(27) Clitics in enclisis (after a host ending in a consonant)

\begin{tabular}{|c|c|c|c|c|c|}
\hline & & & & & \\
\hline & \multirow{2}{*}{$\begin{array}{l}\text { SingLE } \\
\text { CLITICS }\end{array}$} & & $\begin{array}{l}\text { Clitic } \\
\text { olumn c }\end{array}$ & $\begin{array}{l}\text { LUSTERS } \\
\text { ics + ACC cli }\end{array}$ & \\
\hline & & $/ 1 / \sim / 1 \mathrm{o} /$ & $/ \mathrm{la} /$ & $/ \mathrm{lz} / \sim / \mathrm{loz} /$ & /lez/ \\
\hline$/ \mathrm{m} /{ }^{\prime} 1 \mathrm{sG}$ ' & [me] & [mel] & [mela] & [mels] & [meles] \\
\hline$/ \mathrm{t} /$ '2SG' & [te] & [tel $]$ & [tela] & [tels] & [teles] \\
\hline /S/ '3REFL' & [se] & [sell] & [sela] & [sels] & [seles] \\
\hline$/ \mathrm{moz} /$ ' $1 \mathrm{PL}$ ' & {$[\mathrm{mos}]$} & [mol] & [mola] & [mols] & [moles] \\
\hline /voz/ '2PL' & [vos] & [vol] & [vola] & [vols] & [voles] \\
\hline /li/ '3DAT.SG' & [li] & [lil $]$ & [lila & [lils] & [liles] \\
\hline /lz/ /loz/ '3DAT.PL' & {$[\operatorname{los}]$} & [lozlo] & [lozla] & - & $-^{13}$ \\
\hline$/ 1 / \sim / 10 /$ '3ACC.MASC.SG' & [1o] & & & & \\
\hline /la/ 'ЗАCC.FEM.SG' & [la] & & & & \\
\hline /lz/ /loz/ '3ACC.MASC.PL' & {$[\operatorname{los}]$} & & & & \\
\hline /lez/ 'ЗАCC.FEM.PL' & [les] & & & & \\
\hline
\end{tabular}

The alternation between proclitic [a] and enclitic [e] in epenthetic sites cannot be explained as a general neutralization phenomenon, because of the lack of neutralization elsewhere. For example, $3^{\text {rd }}$ person accusative feminine clitics $/ \mathrm{la} /$ and $/$ lez/ (where the

${ }^{13}$ The enclitic combination of $3^{\text {rd }}$ person plural dative plus $3^{\text {rd }}$ person plural accusative clitics is not included in Garcia \& Beltran (1994), probably due to the general tendency to avoid these clusters in postverbal position in the variety under study (see Beltran 2005: I, 100-101). 
vowels stand for the feminine morph) maintain the quality of the input vowels regardless of their position with respect to the host. ${ }^{14}$ From an OT perspective, the quality of input vowels is preserved invariable by faithfulness constraints, while the selection of the epenthetic vowel is determined by the effects of Positional Markedness.

As argued, in general the more sonorous a vocalic peak is, the better it is $(* \mathrm{P} / \mathrm{e}$ $>$ *P/a); but for epenthetic vocalic peaks the contrary is true too, due to the prosodically weak position that epenthesis occupies $\left(* \mathrm{P}_{\mathrm{EP}} / \mathrm{a}>>* \mathrm{P}_{\mathrm{EP}} / \mathrm{e}\right)$. Additionally, since the preverbal and the postverbal position do not have the same degree of prominence, the ranking for epenthetic syllable nuclei can split depending on the site of the epenthesis, as shown in (28).

(28) a. ${ }^{*} \mathrm{P}_{\mathrm{PROCLEP}} / \mathrm{a}>>* \mathrm{P}_{\mathrm{PROCLEp}} / \mathrm{e} \quad$ (proclisis, strong position)

b. ${ }^{*} \mathrm{P}_{\mathrm{ENCLEP}} / \mathrm{a}>>* \mathrm{P}_{\mathrm{ENCLEP}} / \mathrm{e} \quad$ (enclisis, weak position)

Since enclitics are placed at the end of the clitic group, inserting a vowel (irrespective of its quality) as a syllable nucleus in that position (i.e. final position, a relatively weak position) would be more costly than inserting the same vowel in proclitic position (i.e. initial position, a relatively strong position). The ranking in (29),

\footnotetext{
${ }^{14}$ Some authors derive the two surface vowels of the clitics [la] and [les] from a unique feminine morph /a/, by appealing to specific changes that turn /a/ into [e] when it is followed by a coda-ending morph (as the plural morph /z/ in /laz/, [les]) (cf. Viaplana 1992: 403-404). For expository reasons, we instead adopt the alternative view of phonologically conditioned allomorphy, i.e. /a/ /e/ (cf. Mascaró 1986: 94). In any case, the important fact to remark here is that, contrary to the distribution of [a] and [e] in epenthetic sites, the distribution of [a] and [e] in the feminine clitics la and les is not related to the part of the prosodic domain in which they appear, because they surface as [la] and [les] whether in proclisis or in enclisis. (More details on vowel reduction in Valencian Catalan appear in Lloret \& Jiménez 2008.)
} 
with the family of constraints against epenthetic vowels in enclisis at the top, would be the default option:

(29) $* \mathrm{P}_{\mathrm{ENCLEP}} / \alpha$ (enclisis) $>>* \mathrm{P}_{\mathrm{PROCLEP}} / \alpha$ (proclisis)

To complete the analysis, we need to include the faithfulness constraints that protect the features of input vowels. For our purposes, the IDENT constraint that preserves $[ \pm$ low] specifications, (30), is enough to ensure that the low underlying vowel /a/ will not surface as [e] and that the non-low vowel /e/ will not surface as [a]. Remarkably, epenthetic vowels do not have underlying features; therefore, their specifications cannot be protected by faithfulness (input-output) constraints.

(30) IDENT[ $[ \pm$ low $]-V(\operatorname{ID}[ \pm$ low $]-V)$ : The value for $[ \pm$ low $]$ in the $\mathrm{I}$ is the same as that of its correspondent in the $\mathrm{O}$.

The relevant ranking for Pedreguer is presented in (31), where constraints referred to optimal syllable nuclei in general $(* \mathrm{P} / \mathrm{e}>>* \mathrm{P} / \mathrm{a})$ crucially appear below some of the constraints penalizing the insertion of vowels in enclisis and above some of the constraints penalizing the insertion of vowels in proclisis.

$$
\begin{aligned}
& \mathrm{ID}[ \pm \text { low }]-\mathrm{V}, \quad * \mathrm{P}_{\mathrm{EnCLEp}} / \mathrm{a} \quad>\quad * \mathrm{P}_{\mathrm{EnCLEF}} / \mathrm{e}, \quad * \mathrm{P} / \mathrm{e} \quad>\quad * \mathrm{P} / \mathrm{a}, \quad * \mathrm{P}_{\mathrm{PROCLEP}} / \mathrm{a} \quad> \\
& * \mathrm{P}_{\mathrm{PROCLEP}} / \mathrm{e}
\end{aligned}
$$

Tableaux (32) and (33) illustrate how the optimal candidates are selected in varieties with regular [a] epenthesis in proclitic position and [e] elsewhere. In enclisis (32), the candidate with epenthetic [e], (32a), is selected due to the non-prominent position the clitic cluster occupies, although [a] would be in general a better peak (since *P/e dominates *P/a). Contrariwise, in proclisis (33), the candidate with epenthetic [a], 
(33b), is selected because it contains the best possible nucleus and therefore satisfies *P/e; this constraint crucially dominates the constraint banning [a] as epenthesis in proclisis $\left({ }^{*} \mathrm{P}_{\mathrm{PROCLEP}} / \mathrm{a}\right)$, which appears in a low position in the ranking due to the relatively strong position in which epenthetic proclitic segments surface.

(32) Input: porta /m\#1/ 'bring him to me'

\begin{tabular}{|c|c:c|c:c|c|}
\hline Candidates & $\mathrm{ID}[ \pm \mathrm{low}]-\mathrm{V}$ & $* \mathrm{P}_{\mathrm{ENCLEP}} / \mathrm{a}$ & $* \mathrm{P}_{\mathrm{ENCLEP}} / \mathrm{e}$ & $* \mathrm{P} / \mathrm{e}$ & $* \mathrm{P} / \mathrm{a}$ \\
\hline a. mel & & & $*$ & $*$ & \\
\hline b. mal & & $* !$ & & & $*$ \\
\hline
\end{tabular}

(33) Input: /m\#l/ porta 's/he brings him to me'

\begin{tabular}{|c|c|c|c|c|c|}
\hline Candidates & $\mathrm{ID}[ \pm$ low $]-\mathrm{V}$ & $* \mathrm{P} / \mathrm{e}$ & $* \mathrm{P} / \mathrm{a}$ & $* \mathrm{P}_{\text {PROCLEP }} / \mathrm{a}$ & $* \mathrm{P}_{\mathrm{PROCLEP}} / \mathrm{e}$ \\
\hline a. mel & & $* !$ & & & * \\
\hline b. mal & & & $*$ & $*$ & \\
\hline
\end{tabular}

Finally, tableaux (34) and (35) illustrate how the optimal candidates are selected in the presence of input vowels, whose underlying specifications are protected by the faithfulness constraint IDENT[ \pm low $]-\mathrm{V}$ even when, as in this case, they are not the best possible syllable nuclei in general.

(34) Input: porta /lez/ 'bring them (FEM)'

\begin{tabular}{|c|c|c|c|c|c|}
\hline Candidates & $\mathrm{ID}[ \pm$ low $]-\mathrm{V}$ & $* \mathrm{P}_{\mathrm{ENCLEP}} / \mathrm{a}$ & $* \mathrm{P}_{\text {ENCLEP }} / \mathrm{e}$ & $* \mathrm{P} / \mathrm{e}$ & $* \mathrm{P} / \mathrm{a}$ \\
\hline a. les & & & & * & \\
\hline b. las & $* !$ & & & & * \\
\hline
\end{tabular}


(35) Input: /lez/ porta 's/he brings them (FEM)'

\begin{tabular}{|c|c|c|c:c|c|}
\hline Candidates & $\mathrm{ID}[ \pm \mathrm{low}]-\mathrm{V}$ & $* \mathrm{P} / \mathrm{e}$ & $* \mathrm{P} / \mathrm{a}$ & $* \mathrm{P}_{\mathrm{PROCLEP}} / \mathrm{a}$ & $* \mathrm{P}_{\mathrm{PROCLEP}} / \mathrm{e}$ \\
\hline a. les & & $*$ & & & \\
\hline b. las & $* !$ & & $*$ & & \\
& & & & & \\
\hline
\end{tabular}

\section{Conclusion}

Positional prominence exerts a twofold influence on segmental features. On the one hand, faithfulness requirements are stronger when a site is more relevant. As a result of this tendency, we have examined cases of exceptional preservation of features due to the strong position in which the bearing segments appear. Typically, the exceptions are limited to stressed vowels, but they have also been attested in word-initial position (as in the preservation of mid-open vowels in some Valencian varieties) and in pretonic syllables (as in the preservation of pretonic open mid-vowels in Galician).

On the other hand, the most prominent features tend to be linked to the most relevant positions and, inversely, the least prominent features tend to associate with the least salient positions. Thus, there is a tendency towards the accumulation of prominent and non-prominent properties in strong and weak sites, respectively (a kind of sum-up effect). As an important novelty of this work, we have discussed several cases in which positional prominence - either that of word-initial position or that of stressed syllables couples with a higher degree of segmental sonority. Among other phenomena, we have presented the tendency to open the stressed vowel $o$ in word-initial syllables in Catalan and the trend to surface as open the mid-vowels that appear in stressed position of loanwords in some Romance languages. Similarly, we have related the preference for the selection of [a] as a vowel epenthesis in preverbal clitics in Valencian Catalan to the 
fact that, in every domain, initial syllables are more salient than final syllables; in this case, preverbal clitics are more salient than postverbal clitics, in which [e], being less sonorous than [a], is systematically selected as the default epenthetic vowel.

In conclusion, exploration of the role of prominence in phonology is a productive area of research. In appealing to recent OT insights on Positional Faithfulness and Positional Markedness effects, this work has shed new light on several word-initial vocalic adjustments that have been unsatisfactorily explained in the past and promises much more for analyses of other 'obscure' changes.

\section{REFERENCES}

Alderete, John. 1995. Faithfulness to prosodic heads. Ms., University of Massachusetts, Amherst.

Badia i Margarit, Antoni M. 1968. Predominio de las vocales abiertas ę y o en el catalán de Barcelona, Revista de Filología Española 49 (1966), 315-320. Reprinted in Sons i fonemes de la llengua catalana. 209-214. Barcelona: Publicacions de la Universitat de Barcelona, 1988.

Badia i Margarit, Antoni M. 1970. Les vocals tòniques $e$ i $o$ en el català de Barcelona. Assaig d’anàlisi fonològica de la situació actual. Estudis Romànics 12 (1963-1968), 119-172. Reprinted in Sons i fonemes de la llengua catalana. 141-190. Barcelona: Publicacions de la Universitat de Barcelona, 1988.

Barnes, Jonathan. 2002. The phonetics and phonology of positional neutralization. Ph.D. dissertation, University of California, Berkeley. Published as Strength and weakness at the interface: Positional neutralization in phonetics and phonology. Berlin: Mouton de Gruyter, 2006. 
Beckman, Jill N. 1998. Positional faithfulness. Ph.D. dissertation, University of Massachusetts at Amherst. Published as Positional faithfulness: an optimality theoretic treatment of phonological asymmetries. New York: Garland, 2001. $<$ http://roa.rutgers.edu>, \# 234.

Beltran i Calvo, Vicent. 1997. El parlar de Benissa. Alacant: Ajuntament de Benissa, Institut de Cultura Juan Gil-Albert.

Beltran i Calvo, Vicent. 2005. El parlar de la Marina Alta. 2 vols. Alacant: Departament de Filologia Catalana, Universitat d’Alacant.

Blevins, Juliette. 2003. The independent nature of phonotactic constraints. An alternative to syllable-based approaches. In Caroline Féry \& Ruben van de Vijver (eds.), The syllable in Optimality Theory. 375-493. Cambridge: Cambridge University Press.

Bonet, Eulàlia \& Maria-Rosa Lloret. 2005. More on alignment as an alternative to domains: the syllabification of Catalan clitics. Probus. International Journal of Latin and Romance Linguistics 17.1, 37-78.

Bonet, Eulàlia, Maria-Rosa Lloret \& Joan Mascaró. 2007. Domain and directionality in Catalan ATR harmony. Paper presented at the workshop "Harmony in the Languages of the Mediterranean”, $4^{\text {th }}$ Old-World Conference in Phonology. Rhodes, University of the Aegean, University of Crete. <http://www.uv.es/foncat>, \# 16.

Cabré Monné, Teresa. 2002. Altres mecanismos de formació de mots. In Joan Solà, Maria-Rosa Lloret, Joan Mascaró \& Manuel Pérez Saldanya (eds.), Gramàtica del català contemporani. Vol. 1, 889-932. Barcelona: Empúries.

Cabré Monné, Teresa. 2009. Vowel reduction and vowel harmony in Eastern Catalan loanword phonology. In Marina Vigário, Sónia Frota \& M. João Freitas (eds.), 
Phonetics and Phonology. Interactions and interrelations. 267-285. Amsterdam/Philadelphia: John Benjamins.

Cabré Monné, Teresa. 2010. El sistema vocàlic del català central i l’adaptació dels manlleus. In Kálmán Faluba \& Ildikó Szijj (eds.), Actes del Catorzè Col·loqui Internacional de Llengua i Literatura catalanes, Universitat Eötvös Loránd de Budapest, 4-9 de setembre de 2006. Vol. 3, 111-120. Barcelona: Publicacions de l’Abadia de Montserrat.

Cabré Monné, Teresa \& Pilar Prieto. 2006. Exceptional hiatuses in Spanish. In Fernando Martínez-Gil \& Sonia Colina (eds.), Optimality-theoretic studies in Spanish phonology. 205-238. Amsterdam/Philadelphia: John Benjamins.

Chitoran, Ioana, Louis Goldstein \& Dani Byrd. 2002. Gestural overlap and recoverability: Articulatory evidence from Georgian. In Carlos Gussenhoven \& Natasha Warner (eds.), Papers in Laboratory Phonology 7. 419-447. Cambridge: Cambridge University Press.

Coromines, Joan. 1971. Lleures i converses d'un filòleg. Barcelona: Club Editor.

Crosswhite, Katherine. 1999. Vowel reduction in Optimality Theory. Ph.D. dissertation, UCLA. Published in London / New York: Routledge, 2001.

Crosswhite, Katherine. 2004. Vowel reduction. In Bruce Hayes, Robert Kirchner \& Donca Steriade (eds.), Phonetically based phonology. 191-231. Cambridge: Cambridge University Press.

Donegan, Patricia J. 1978. On the Natural Phonology of vowels. Ph.D. dissertation, Ohio State University, Columbus. Reprinted as The Ohio State Working Papers in Linguistics 23. Ohio State University: Columbus, 1978. 
$D P L G=$ Dicionario de pronuncia da lingua galega. Online <http://ilg.usc.es/pronuncia/>. 30 Mar. 2012.

DRAG = Dicionario $d a$ Real Academia Galega. Online <http://www.realacademiagalega.org/dicionario/>. 30 Mar. 2012.

Fabra, Pompeu. 1906. Les E toniques du Catalan, Revue Hispanique 15, 9-23.

Franceschi, Temistocle. 1968. Vocale incerta, vocale aperta; consonante incerta, consonante sonora. In Antonio Quilis (ed.), XI Congreso Internacional de Lingüística y Filología Románica: actas. Vol. 3, 1105-1113. Madrid: Revista de Filología Española.

Freixeiro, Xosé Ramón. 2006. Gramática da lingua galega. I. Fonética e fonoloxía. $2^{\text {nd }}$ edn. Vigo: A Nosa Terra.

Garcia, Josepa \& Vicent Beltran. 1994. El parlar de Pedreguer. Pedreguer: Ajuntament de Pedreguer / Institut d’Estudis Comarcals de la Marina Alta.

Gulsoy, Joseph. 1993. Estudis de gramàtica històrica. València/Barcelona: Institut Interuniversitari de Filologia Valenciana / Publicacions de l’Abadia de Montserrat.

Hawkins, John A. \& Anne Cutler. 1988. Psycholinguistic factors in morphological asymmetry. In John A. Hawkins (ed.), Explaining language universals. 280-317. Oxford: Blackwell.

Jiménez, Jesús \& Maria-Rosa Lloret. 2010. Efectes de prominència en canvis vocàlics obscurs. Paper presented at XXVI Congrés Internacional de Lingüística i Filologia Romàniques. València, Universitat de València. <http://www.uv.es/foncat>, \# 34.

Kenstowicz, Michael. 2010. Vocale incerta, vocale aperta. Paper presented at 40th Linguistic Symposium on Romance Languages. Seattle, University of Washington. 
Lloret, Maria-Rosa \& Jesús Jiménez. 2008. Marcatge posicional i prominència en el vocalisme àton, Caplletra. Revista Internacional de Filologia 45, 55-91. $<$ http://www.uv.es/foncat>, \# 21.

Mascaró, Joan. 1986. Morfologia. Barcelona: Enciclopèdia Catalana.

Mascaró, Joan. 2008. La distribució de les vocals mitjanes tòniques en català central, Caplletra. Revista Internacional de Filologia 44, 75-102. <http://www.uv.es/foncat>, \# 24.

Mascaró, Joan. 2011. Efectes accentuals i sil·làbics sobre la distribució de les vocals mitjanes en català central. In Maria-Rosa Lloret \& Clàudia Pons (eds.), Noves aproximacions a la fonologia i la morfologia del català. Volum d'homentage a Max W. Wheeler. 405-426. Alacant: Institut Interuniversitari de Filologia Valenciana.

Menéndez Pidal, Ramón. 1985. Manual de gramática histórica española. $18^{\text {th }}$ edn. Madrid: Espasa Calpe.

Migliorini, Bruno. 1945. Pronunzia fiorentina o pronunzia romana? Firenze: Sansoni. Migliorini, Bruno. 1990. La lingua italiana nel Novecento. Firenze: Le Lettere.

Moll, Francesc de Borja. 2006. Gramàtica històrica catalana. València: Universitat de València.

Nooteboom, Sieb G. 1981. Lexical retrieval from fragments of spoken words: beginnings vs. endings, Journal of Phonetics 9, 407-424.

Ohala, John J. \& Haruko Kawasaki-Fukumori. 1997. Alternatives to the sonority hierarchy for explaining segmental sequential constraints. In Stig Eliasson \& Ernst Håkon Jahr (eds.), Language and its ecology: Essays in memory of Einar Haugen. 343-365. Berlin: Mouton de Gruyter. 
Pi-Mallarach, Josep. 1997. L’obertura de les vocals mitjanes en una mostra de neologismes del català. Ph.D. dissertation, Universitat Autònoma de Barcelona, Bellaterra.

Prince, Alan \& Paul Smolensky. 1993/2004. Optimality Theory. Constraint interaction in Generative Grammar. Malden/Oxford/Carlton: Blackwell. <http:/rutgers.roa.edu>, \# 537.

Sancho Cremades, Pelegrí. 1995. El valencià col·loquial de la vila de Canals. Canals: Ajuntament de Canals.

Viaplana, Joaquim. 1992. La flexió verbal regular del valencià. In Antoni Ferrando (ed.), Miscel·lània Sanchis Guarner. Vol. 3, 381-423. Barcelona: Publicacions de l’Abadia de Montserrat.

Wheeler, Max W. 2005. The phonology of Catalan. Oxford: Oxford University Press. 